\title{
Vaginal Villous Adenoma
}

National Cancer Institute

\section{Source}

National Cancer Institute. Vaginal Villous Adenoma. NCI Thesaurus. Code C40259.

An adenoma that arises from the vagina and is characterized by a villous architectural pattern. 